\title{
Chemical Composition and Bioactivity of Three Plant Essential Oils against Tribolium castaneum (Herbst) and Sitophilus oryzae (L.) Awadalla, S. S. ${ }^{1}$; G. M. Zayed ${ }^{2}$ and A. S. Hashem ${ }^{2}$ \\ ${ }^{1}$ Economic Entomology Department, Faculty of Agriculture, Mansoura University, Egypt. \\ ${ }_{2}^{2}$ Plant Protection Research Institute, Sakha, Kafr El-Sheikh, Egypt.
}

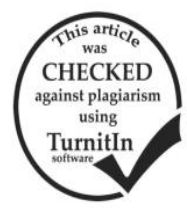

\section{ABSTRACT}

Three essential oils extracted from German chamomile, Matricaria chamomilla, Anise, Pimpinella anisum and cumin, Cuminum cyminum were assessed against two of the major stored grain insect species, Sitophilus oryzae (L.) and Tribolium castaneum (Herbst). The chemical composition of the essential oils was determined by gas chromatography (GC) and GC/mass spectrometry. The bioactivity of the oils determined was assessed against both species. A concentration of $100000 \mathrm{ppm}$, essential oils caused $100 \%$ mortality of S.oryzae after $96 \mathrm{~h}$. of exposure, whereas, T. castaneum were more tolerant to the oils than $S$. oryzae. At this concentration, the values of $F_{1}$ progeny production, progeny reduction $(\%)$ and grain weight loss $(\%)$ of both insect species were lower than other concentrations. Eventually, all oils exhibited a negative impact on some biological aspects of both insects. These results highlight the potential of these oils as grain protectants and antifeedants, and consequently could be suitable for the management of insect pests in grain stores.

Keywords: Bioactivity, inhibitors, progeny production, tolerant.

\section{INTRODUCTION}

During storage, grains are exposed to the attack of numerous by insects, fungi and vertebrate pests from time of harvest to consumption (Manickavasagan et al. 2008).Insect pests, mainly weevils and beetles, play a significant role in reducing the quality and quantity of stored grain and causing yield losses of about $75 \%$ in developing countries (Nakakita. 1998 ; Papachristos and Stamopoulos. 2002). Additionally, consumption of food commodities, contaminate the grains with shed skins, feces and toxins (Arthur et al. 2006).

The rice weevil, Sitophilus oryzae L. (Coleoptera: Cucurlionidae) and red flour beetle, Tribolium castaneum Herbst. (Coleoptera: Tenebrionidae) are of the most destructive insect pests of stored grains worldwide (Yoon et al. 2007) causing higher reduction in quality and quantity of food items. From the medical and allergic point of view, both species have great importance.

Currently, control of these insect pests is mainly based on synthetic insecticides (Sousa et al. 2009). Nevertheless, the huge use of these chemicals has caused several problems such as destruction of beneficial fauna, health hazards, accumulative residues of pesticides, contamination of underground water and rivers and development of insect resistance and pest resurgence. Therefore, there is a fundamental need to develop new types of safe, easily prepared and environmental, convenient and low cost alternatives (Ebadollahi 2011). Bioinsecticides, especially essential oils offer one of the most successful preservation materials suitable for a wide range of agricultural and food products (George et al. 2014). Essential oils and their constituents have different modes of action that can be associated with their potential for insect mortality (Copping and Menn 2000). It has been proven that essential oils surpassed the synthetic insecticides as inhibitors for oviposition, feeding, development and adult emergence for stored grain insect pests. As a part of future applications for stored product insect control, essential oils must be evaluated to determine their feasibility as alternative control methods rather than the traditional insecticides.
Therefore, this study aimed to identify the chemical composition and bioactivity of the essential oils that extracted from German chamomile, Matricaria chamomilla (Chompositae); Anise, Pimpinella anisum (Umbelliferae) and cumin, Cuminum cyminum (Apiaceae) against rice weevil Sitophilus oryzae L. and red flour beetle Tribolium castaneum Herbst.

\section{MATERIALS AND METHODS}

Plant oils

The dry flowers of Matricaria chamomilla and seeds of Pimpinella anisum and Cuminum cyminum were collected from different areas of Egypt. Direct steam distillation technique described by Hashem Brothers Company for Essential Oils and Aromatic Products (Kafr-Elsohby, Kalyoubeya, Egypt) was used for obtaining crude essential oils. In which, the targeted plant parts were placed in a container equipped with condenser at which steam was passed through it carrying essential oils which condensed the vapor. Then, condensed vapor was received in a receptor separation of oil from water. Extraction time and background information about the plant species are summarized in Table 1. The excess water was removed out by adding anhydrous sodium sulphate. The obtained oil was filtered twice and stored in dark glass bottles in a refrigerator at $4{ }^{\circ} \mathrm{C}$ till their application for bioassays. Identification of oil components (GC-MS analysis)

Chemical composition of essential oils was identified with gas chromatography-mass spectrometry (GC/MS) using HP5890 system with a HP column (60 meter X 0.25 millimeter, $0.25 \mu \mathrm{m}$ film thickess). The oils were detected using flame ionization detector (FID). Nitrogen and hydrogen were the stationary phase. Initial temperature was $60^{\circ} \mathrm{C}$ and maximum temperature was $250{ }^{\circ} \mathrm{C}$. The injector temperature was $240^{\circ} \mathrm{C}$. Relative amounts of oils were calculated from peaks total area by apparatus software. The compounds were identified by matching the mass spectra data with those held in a computer library (Wiley 275 L). All steps of sample preparation, extraction and analysis procedures were carried out in the laboratory of Hashem Brothers Company (Abdel Moneim Riad St. Giza, Egypt). 
Table 1. Plant species used and their oil information.

\begin{tabular}{lccc}
\hline $\begin{array}{l}\text { Plant species } \\
\text { Information }\end{array}$ & Matricaria chamomilla & Pimpinella anisum & Cuminum cyminum \\
\hline Family & Chompositae & Umbelliferae & Apiaceae \\
Common Name & German chamomile & Anise & Cumin \\
Tissue collected & Dry flowers & Seeds & Seeds \\
Extraction time & Direct steam for $12 \mathrm{~h}$. & Direct steam for $8 \mathrm{~h}$. & Direct steam for $12 \mathrm{~h}$. \\
\hline
\end{tabular}

\section{Culture of insects}

Adults of $S$. oryzae and T. castaneum were used in the laboratory experiments. T. castaneum was reared on broken wheat grains mixed with $5 \%$ dried yeast and $S$. oryzae was reared on whole wheat grains in incubator at $25 \pm 1{ }^{\circ} \mathrm{C}$ and $60 \pm 3$ r.h. \%, and $10 \mathrm{~L}: 14 \mathrm{D}$ photoperiod. Unsexed adults used in the experiments were 7-14 days old.

Bioassays

All bioassay experiments were conducted at $27 \pm 2{ }^{\circ} \mathrm{C}, 65 \pm 5 \% \mathrm{RH}$ and $12 \mathrm{~L}: 12 \mathrm{D}$ photoperiod until new adult emergence.

A direct contact assay was applied to evaluate the activity of the tested oils against the adults of $S$. oryzae and T. castaneum. Series of concentrations were prepared in acetone, and completely mixed with $20 \mathrm{~g}$ of (whole wheat or broken wheat) grains in $50 \mathrm{ml}$ plastic containers to give the concentrations of 25000, 50000, 75000 and $100000 \mathrm{ppm}$, beside the control treatment which treated with acetone alone. The solvent was allowed to evaporate for $2 \mathrm{~min}$ prior to the introduction of insects. Adults of the tested insects were released in groups of twenty unsexed into $50 \mathrm{ml}$ plastic containers containing the one of the prepared concentrations.

All the treatments were replicated three times. Mortality was recorded after $48 \mathrm{~h}, 72 \mathrm{~h}$ and $96 \mathrm{~h}$ from treatment and corrected according to Abbott's formula (Abbott. 1925). After $96 \mathrm{~h}$, all the survival insects were separated from the grains and discarded. The grains were left inside the jars until the emergence of $F_{1}$ progeny and \% Weight grain losses were counted (Nukenine et al. 2007). The $F_{1}$ progeny were recorded after 60 days from infestation for insects.

\section{Statistical analysis}

The data of mortality, loss grain weight, and antifeedant were analyzed by one-way analysis of variance (ANOVA) using SigmaPlot 12.0 software. In case of significant means were separated using Fisher LSD test at 0.05 probability level.

\section{RESULTS}

\section{Chemical components of essential oils}

The results of GC/MS analysis of the essential oils obtained by hydrodistillation are summarized in Table 2 . The main compounds $(>1 \%)$ of essential oils were identified by matching their spectra with available one in the library. Total yield of the identified essential oils gave $86.66 \%, 92.50 \%$ and $51.35 \%$ of $M$. chamomilla, P. anisum, and C. cyminum, respectively. Bisabolol oxide A $(40.54 \%)$, 7, 11-dimethyl-3methylene (17.01\%), and Bisabolol oxide B (7.43\%) were the major components in $M$. chamomilla. For oil of $P$. anisum oil, more than three quarters of the oil was identified as Transanisole (86.74\%). Whilst, $\gamma$-Terpinene $(15.76 \%)$ and Benzene methanol (11.32\%) followed by Beta Pinene (10.37\%) were the major components of $C$. cyminum.

Table 2. Main chemical constituents of the extracted oils

\begin{tabular}{lcc}
\hline Main Components & Retention time (min) & Concentration(\%) \\
\hline German Chamomile Flowers ( Matricaria chamomilla) & & 17.01 \\
7,11-dimethyl-3-methylene & 28.58 & 1.90 \\
Germacrene-D & 29.35 & 1.26 \\
Germacrene-B & 29.94 & 1.14 \\
3,7,11-Trimethyle & 30.45 & 1.11 \\
5,8-Dimethylisoquinoline & 30.64 & 6.43 \\
Alpha-bisabolol & 36.52 & 7.43 \\
Bisabolol oxide B & 35.28 & 3.52 \\
Chamazulen & 39.23 & 40.54 \\
Bisabolol oxide A & 40.52 & 6.32 \\
Lend-in-dicycloether & 44.87 & 1.68 \\
Anise seeds ( Pimpinella anisum ) & & 86.74 \\
Methyl chavicol & 14.61 & 4.08 \\
Transanisole & 18.94 & 11.32 \\
Estragol & 25.68 & 15.76 \\
Cumin seeds ( Cuminum cyminum ) & & 10.37 \\
Benzene methanol & 10.94 & 7.45 \\
$\gamma$-Terpinene & 11.23 & 6.45 \\
Beta Pinene & 8.56 & \\
P- cymine & 12.05 & 8.25 \\
1-phenil-1-butanol & & \\
& & \\
\hline
\end{tabular}


Bioassay

The results given in Table 3 and 4 described the mortality, $F_{1}$ progeny production, reduction percentage in progeny and weight grain loss of S.oryzae and T. castaneum exposed to different concentrations of $M$. chamomilla, $P$. anisum, and C. cyminum essential oils mixed with grain diet. Generally, results showed that all concentrations were less toxic against T.castaneum than S.oryzae. The mortality caused by these essential oils varied among concentrations. Mortality tended to increase with ascending concentrations as time of exposure multiplied. The oil of C. cyminum was most effective against S.oryzae than oils of $M$. chamomilla and $P$. anisum, whereas, the oil of $P$. anisum was more effective against T.castaneum than oils of M. chamomilla and C. cyminum. The complete mortality occurred at 100000 ppm after $72 \mathrm{~h}$ exposure to $C$. cyminum and $P$. anisum for S.oryzae and T.castaneum, respectively, with significant differences with control.

Table 3. Mortality, $F_{1}$ progeny production, reduction and weight grain loss of Sitophilus oryzae exposed to essential oils mixed with wheat or grains at different concentrations

\begin{tabular}{|c|c|c|c|c|c|c|c|}
\hline \multirow[b]{2}{*}{ Source of oil } & \multirow[b]{2}{*}{ Con. (ppm) } & \multicolumn{3}{|c|}{ Mean \% Adult Mortality ( \pm SE) } & \multirow{2}{*}{$\begin{array}{c}\text { No. } F_{1} \\
\text { progeny } \\
(\text { mean } \pm \mathrm{SE})\end{array}$} & \multirow{2}{*}{$\begin{array}{l}\text { Reduction } \\
\text { in progeny } \\
\text { number } \%\end{array}$} & \multirow{2}{*}{$\begin{array}{c}\text { Grain } \\
\text { weight loss } \\
\%\end{array}$} \\
\hline & & $48 \mathrm{~h}$ & $72 \mathrm{~h}$ & $96 \mathrm{~h}$ & & & \\
\hline \multirow{5}{*}{ P. anisum } & 25000 & $26.67 \pm 0.28 \mathrm{c}$ & $46.67 \pm 0.27 \mathrm{~b}$ & $60.12 \pm 0.47 \mathrm{~b}$ & $10.67 \pm 0.27 \mathrm{~b}$ & $94.12 \mathrm{~b}$ & $1.15 \mathrm{~b}$ \\
\hline & 50000 & $56.67 \pm 0.67 \mathrm{~b}$ & $83.33 \pm 0.33 \mathrm{~b}$ & $86.67 \pm 0.33 \mathrm{~b}$ & $2.67 \pm 0.23 \mathrm{c}$ & $98.53 \mathrm{a}$ & $0.62 \mathrm{~b}$ \\
\hline & 75000 & $73.33 \pm 0.33 b$ & $90.00 \pm 0.57 \mathrm{a}$ & $100.00 \pm 0.00 \mathrm{a}$ & $0.00 \pm 0.00 \mathrm{~d}$ & $100.00 \mathrm{a}$ & $0.24 \mathrm{~b}$ \\
\hline & 100000 & $83.33 \pm 0.88 \mathrm{a}$ & $95.66 \pm 0.22 \mathrm{a}$ & $100.00 \pm 0.00 \mathrm{a}$ & $0.00 \pm 0.00 \mathrm{~d}$ & $100.00 \mathrm{a}$ & $0.13 \mathrm{~b}$ \\
\hline & Control & $0.00 \pm 0.00 \mathrm{~d}$ & $0.00 \pm 0.00 \mathrm{c}$ & $0.00 \pm 0.00 \mathrm{c}$ & $181.43 \mathrm{a}$ & $00.00 \mathrm{c}$ & $24.85 \mathrm{a}$ \\
\hline \multirow{5}{*}{$\begin{array}{l}\text { M. } \\
\text { chamomilla }\end{array}$} & 25000 & $16.67 \pm 0.27 b$ & $63.33 \pm 0.27 \mathrm{bc}$ & c $73.33 \pm 0.28 \mathrm{~b}$ & $19.67 \pm 0.34 \mathrm{~b}$ & $89.16 \mathrm{c}$ & $2.16 \mathrm{~b}$ \\
\hline & 50000 & $20.33 \pm 0.03 b$ & $60.00 \pm 0.57 \mathrm{c}$ & $76.67 \pm 0.33 \mathrm{~b}$ & $11.33 \pm 0.67 \mathrm{c}$ & $93.75 \mathrm{~b}$ & $1.43 \mathrm{~b}$ \\
\hline & 75000 & $36.67 \pm 0.33 \mathrm{a}$ & $73.33 \pm 0.33 \mathrm{~b}$ & $90.0 \pm 0.57 \mathrm{a}$ & $7.67 \pm 0.41 \mathrm{~d}$ & $95.77 \mathrm{~b}$ & $0.89 \mathrm{~b}$ \\
\hline & 100000 & $40.33 \pm 0.57 \mathrm{a}$ & $90.33 \pm 0.57 \mathrm{a}$ & $100.00 \pm 0.00 \mathrm{a}$ & $0.00 \pm 0.00 \mathrm{e}$ & $100.00 \mathrm{a}$ & $0.02 \mathrm{~b}$ \\
\hline & Control & $0.00 \pm 0.00 \mathrm{c}$ & $0.00 \pm 0.00 \mathrm{~d}$ & $0.00 \pm 0.00 \mathrm{c}$ & $181.43 \mathrm{a}$ & $00.00 \mathrm{~d}$ & $24.85 \mathrm{a}$ \\
\hline \multirow{5}{*}{ C. сутіпит } & 25000 & $23.67 \pm 0.25 \mathrm{~d}$ & $46.67 \pm 0.27 \mathrm{c}$ & $66.66 \pm 0.27 \mathrm{~b}$ & $7.67 \pm 0.88 \mathrm{~b}$ & $95.78 \mathrm{~b}$ & $0.84 \mathrm{~b}$ \\
\hline & 50000 & $43.33 \pm 0.33 c$ & $83.33 \pm 0.33 b$ & $96.67 \pm 0.33 \mathrm{a}$ & $1.67 \pm 0.57 \mathrm{c}$ & $99.08 \mathrm{a}$ & $0.42 \mathrm{~b}$ \\
\hline & 75000 & $56.67 \pm 0.33 b$ & $93.33 \pm 0.33 \mathrm{a}$ & $100.00 \pm 0.00 \mathrm{a}$ & $0.00 \pm 0.00 \mathrm{~d}$ & $100.00 \mathrm{a}$ & $0.14 \mathrm{~b}$ \\
\hline & 100000 & $80.33 \pm 0.03 a$ & $100.00 \pm 0.00 \mathrm{a}$ & $\mathrm{a} 100.00 \pm 0.00 \mathrm{a}$ & $0.00 \pm 0.00 \mathrm{~d}$ & $100.00 \mathrm{a}$ & $0.01 \mathrm{~b}$ \\
\hline & Control & $0.00 \pm 0.00 \mathrm{e}$ & $0.00 \pm 0.00 \mathrm{~d}$ & $0.00 \pm 0.00 \mathrm{c}$ & $181.43 \mathrm{a}$ & $00.00 \mathrm{c}$ & $24.85 \mathrm{a}$ \\
\hline
\end{tabular}

Different letters in the same column (for each oil) indicate significant differences at the 0.05 levels ( Fisher LSD )

Table 4. Mortality, $\mathrm{F}_{1}$ progeny production, reduction and weight grain loss of Tribolium castaneum exposed to essential oils mixed with wheat or grains at different concentrations

\begin{tabular}{|c|c|c|c|c|c|c|c|}
\hline \multirow{2}{*}{ Source of oil } & \multirow{2}{*}{$\begin{array}{l}\text { Con. } \\
\text { (ppm) }\end{array}$} & \multicolumn{3}{|c|}{ Mean \% Adult Mortality $( \pm$ SE) } & \multirow{2}{*}{$\begin{array}{c}\text { No. }_{1} \\
\text { progeny } \\
(\text { mean } \pm \text { SE) }\end{array}$} & \multirow{2}{*}{$\begin{array}{l}\text { Reduction } \\
\text { in progeny } \\
\text { number } \%\end{array}$} & \multirow{2}{*}{$\begin{array}{c}\text { Grain } \\
\text { weight loss } \\
\%\end{array}$} \\
\hline & & $48 \mathrm{~h}$ & $72 \mathrm{~h}$ & $96 \mathrm{~h}$ & & & \\
\hline \multirow{5}{*}{ P. anisum } & 25000 & $40.33 \pm 0.33 \mathrm{~b}$ & $44.23 \pm 0.31 \mathrm{~b}$ & $50.66 \pm 0.07 \mathrm{~b}$ & $43.33 \pm 0.46 \mathrm{~b}$ & $64.25 \mathrm{c}$ & $2.47 \mathrm{~b}$ \\
\hline & 50000 & $90.33 \pm 0.33 \mathrm{a}$ & $92.67 \pm 0.08 \mathrm{a}$ & $96.67 \pm 0.33 \mathrm{a}$ & $25.33 \pm 0.46 \mathrm{c}$ & $79.10 \mathrm{~b}$ & $1.82 \mathrm{~b}$ \\
\hline & 75000 & $93.33 \pm 0.14 \mathrm{a}$ & $97.33 \pm 0.14 \mathrm{a}$ & $100.00 \pm 0.00 \mathrm{a}$ & $2.67 \pm 0.57 \mathrm{~d}$ & $97.80 \mathrm{a}$ & $0.95 \mathrm{~b}$ \\
\hline & 100000 & $95.33 \pm 0.29 \mathrm{a}$ & $99.12 \pm 0.05 \mathrm{a}$ & $100.00 \pm 0.00 \mathrm{a}$ & $0.00 \pm 0.00 \mathrm{e}$ & $100.00 \mathrm{a}$ & $0.46 \mathrm{~b}$ \\
\hline & Control & $0.00 \pm 0.00 \mathrm{c}$ & $0.00 \pm 0.00 \mathrm{c}$ & $0.00 \pm 0.00 \mathrm{c}$ & $121.23 \mathrm{a}$ & $00.00 \mathrm{~d}$ & $17.53 \mathrm{a}$ \\
\hline \multirow{5}{*}{ M. chamomilla } & 25000 & $16.67 \pm 0.33 \mathrm{ab}$ & $30.33 \pm 0.03 b$ & $46.67 \pm 0.33 \mathrm{~b}$ & $99.33 \pm 0.46 \mathrm{~b}$ & $18.06 \mathrm{~d}$ & $3.49 \mathrm{~b}$ \\
\hline & 50000 & $17.67 \pm 0.34 \mathrm{ab}$ & $43.33 \pm 0.33 b$ & $60.33 \pm 0.55 \mathrm{~b}$ & $70.33 \pm 0.17 \mathrm{c}$ & $41.98 \mathrm{c}$ & $2.99 \mathrm{~b}$ \\
\hline & 75000 & $23.33 \pm 0.33 \mathrm{a}$ & $56.67 \pm 0.33 \mathrm{a}$ & $73.33 \pm 0.55 \mathrm{a}$ & $60.34 \pm 0.17 \mathrm{~d}$ & $50.23 \mathrm{~b}$ & $2.81 \mathrm{~b}$ \\
\hline & 100000 & $29.67 \pm 0.03 \mathrm{a}$ & $61.67 \pm 0.20 \mathrm{a}$ & $80.33 \pm 0.07 \mathrm{a}$ & $46.67 \pm 0.46 \mathrm{e}$ & $61.51 \mathrm{a}$ & $2.09 \mathrm{~b}$ \\
\hline & Control & $0.00 \pm 0.00 \mathrm{~b}$ & $0.00 \pm 0.00 \mathrm{c}$ & $0.00 \pm 0.00$ & $121.23 \mathrm{a}$ & $00.00 \mathrm{e}$ & $17.53 \mathrm{a}$ \\
\hline \multirow{5}{*}{ C. cyminum } & 25000 & $0.00 \pm 0.00 \mathrm{~d}$ & $3.33 \pm 0.33 \mathrm{c}$ & $6.67 \pm 0.33 \mathrm{~d}$ & $114.67 \pm 0.46 \mathrm{~b}$ & $5.42 \mathrm{~d}$ & $4.87 \mathrm{~b}$ \\
\hline & 50000 & $26.67 \pm 0.33 \mathrm{c}$ & $30.33 \pm 0.58 b$ & $43.33 \pm .88 \mathrm{c}$ & $75.67 \pm 0.46 \mathrm{c}$ & $37.58 \mathrm{c}$ & $3.65 \mathrm{~b}$ \\
\hline & 75000 & $36.67 \pm 0.33 \mathrm{~b}$ & $39.33 \pm 0.06 \mathrm{~b}$ & $66.33 \pm 0.32 \mathrm{~b}$ & $49.67 \pm 0.62 \mathrm{~d}$ & $59.03 \mathrm{~b}$ & $2.77 \mathrm{~b}$ \\
\hline & 100000 & $90.33 \pm 0.03 \mathrm{a}$ & $93.00 \pm 0.05 \mathrm{a}$ & $97.67 \pm 0.15 \mathrm{a}$ & $31.34 \pm 0.46 \mathrm{e}$ & $74.15 \mathrm{a}$ & $1.79 \mathrm{~b}$ \\
\hline & Control & $0.00 \pm 0.00 \mathrm{~d}$ & $0.00 \pm 0.00 \mathrm{c}$ & $0.00 \pm 0.00 \mathrm{~d}$ & $121.23 \mathrm{a}$ & $00.00 \mathrm{e}$ & $17.53 \mathrm{a}$ \\
\hline
\end{tabular}

Different letters in the same column (for each oil) indicate significant differences at the 0.05 levels ( Fisher LSD )
All essential oils significantly reduced $\mathrm{F}_{1}$ progeny of
S.oryzae and T.castaneum (Table 3 and 4). The oils of $P$. 100000 ppm at 75000 ppm, and C. cyminum at 75000 and of S.oryzae and achieved $100 \%$ reduction in adult progeny at the same concentrations. Whereas, T.castaneum exhibited higher numbers of T.castaneum adults were recorded alive a cyminum oil followed by those of $M$ comilla at all concentration compared with the control. anisum oil. Subsequently, the rate of increase of $F_{1}$ progeny production of both insects was significantly reduced (Table 3 and 4). Moreover, the weight grain loss was positively associated with the decrease of the mortality percentages and the increase in $\mathrm{F}_{1}$ progeny. more tolerance to all essential oils than S.oryzae. Further, 


\section{DISCUSSION}

Our results on main chemical constituents were similar to those previously reported on $P$. anisum (Hassan and Elhassan 2017), M. chamomilla (Roby et al., 2013) and on C. cyminum (Ladan Moghadam 2016). However, our results disagree with those previously reported on P. anisum (Acimovic et al. 2015), M. chamomilla (Iordache et al., 2009) and on C. cyminum (Moghaddam et al., 2015). Differences observed on both composition and main compounds of essential oils may be due to several factors, such as geographical conditions (Burt 2004), season, climatic, soil variations (Isman and Machial 2006), genetic differences, plant parts extracted and the nutritional status of the plants (Ozcan and Chalchat 2006).

On the other hand, the results of contact bioassay using essential oils showed a strong toxicity, i.e. $100 \%$ mortality in the range of $75000-100000 \mathrm{ppm}$ after $96 \mathrm{~h}$ of exposure compared to untreated controls against both insects. This study showed that $T$. castaneum is relatively more tolerant to the effect of essential oils than $S$. oryzae. The findings of the present investigation show that the oil of $P$. anisum plant has higher effect on T.castaneum reproduction than $M$. chamomilla and $C$. cyminum However, C. cyminum has found to cause a reduction in oviposition, development and an increase in development period of $T$. castaneum probably due to suffocation and inhibition of various biosynthetic processes of the insect (Chaubey 2007).

A significant and/or complete reduction $(100 \%$ inhibition) of the $F_{1}$ progeny of both insects was obtained as a result of parental exposure to the tested botanicals, especially at the highest doses applied. To estimate of plant oils (chamomile, sweet almond and coconut) at 2.5, 3.5, 5.0, 7.0 and $10.0 \mathrm{~mL} / \mathrm{kg}$ against Rhyzopertha dominica in wheat grain to prevent insect infestation, treatments with essential oils at high dose $(10.0 \mathrm{~mL} / \mathrm{kg})$ achieved over $95 \%$ control within $24 \mathrm{~h}$ of exposure compared to untreated controls (Nikpay 2007). Fumigant toxicity of Carum copticum and Cuminum cyminum essential oils have been extensively studied against stored product pests (Shojaaddini et al. 2008). Moreover, the oils could also act as antifeedants, thereby discouraging insect penetration and feeding (Weaver and Subramanyam. 2000).Nenaah and Ibrahim (2011) found that dose of $1.50 \mathrm{ml} \mathrm{cm}$ of the oils of Cinnamomum camphora and Ocimum basilicum completely controlled Trogoderma granarium insect, while $100 \%$ mortality of $T$. castaneum adults was recorded with $P$. anisum oil.

To understand the bioactivities of any essential oil, it is important to know the main chemical components of the target oil in the research. For example, all components of $C$. cyminum were monoterpenes. Monoterpenes have insecticidal toxicity including contact and antifeedant action on stored product insect pests (Ziaee et al., 2014). Also, Hyung et al., (2012) reported that chemical composition of Origanum vulgare L. including thymol and $\gamma$-Terpinene (Those in C. cyminum) showed good fumigant toxicity against $T$. castaneum $\left(\mathrm{LC}_{50}=0.012-0.195 \mathrm{mg} / \mathrm{cm} 3\right)$.
This suggests that different plant extracts does have toxic effects against variety of insects and variability can be attributed to the qualitative and quantitative variation in their chemical constitutions (Bashir et al. 2013; Kanda et al. 2017).

\section{REFERENCES}

Abbott W.S., 1925. A method of computing the effectiveness of an insecticide. J. Econ. Entomol., $18(2), 265-267$.

Acimovic M., Tesevic V., Todosijevic M., Djisalov J., and Oljaca S., 2015. Compositional characteristics of the essential oil of Pimpinella anisum and Foeniculum vulgare grown in Serbia. Botanica Serbica, 39(1), 09-14.

Arthur F.H., Hagstrum D.W., Flinn P.W., Reed C.R., and Phillips T.W., 2006. Insect populations in grain residues associated with commercial Kansas grain elevators. J. Stored Prod. Res., 42(2), 226-239.

Bashir M., Gogi M.D., Ashfaq M., Afzal D.M., Khan M.A., and Ihsan M., 2013. The efficacy of crude aqueous extracts of some plants as grain protectants against the stored grain mite, Rhizoglyphus tritici. Turk. J. Agric. For., 37(5), 585-594.

Burt S., 2004. Essential oils: their antibacterial properties and potential applications in foods - a review. Int. J. Food Microbiol., 94(3), 223-253.

Chaubey M.K., 2007. Toxicity of essential oils from Cuminum cyminum (Umbelliferae), Piper nigrum (Piperaceae) and Foeniculum vulgare (Umbelliferae) against stored-product beetle Tribolium castaneum Herbst (Coleopetera: Tenebrionidae). Electron. J. Environ., Agric. Food Chem., 6, 1719-1727.

Copping L.G., and Menn J.J., 2000. Biopesticides: a review of their action, applications and efficacy. Pest Manage. Sci., 56(8), 651-676.

Duncan D.B., 1955. Multiple range and multiple F tests. Biometrics. 11: 1-42.

Ebadollahi A., 2011. Chemical constituents and toxicity of Agastache foeniculum (Pursh) Kuntze essential oil against two stored-product insect pests. Chilean j. agric. Res., 71(2), 212.

George D.R., Finn R.D., Graham K.M., and Sparagano O.A., 2014. Present and future potential of plantderived products to control arthropods of veterinary and medical significance. Parasites \& vectors, 7(1), 28.

Hassan O.M., and Elhassan I.A., 2017. Characterization of essential oils from fruits of Umbelliferous crop cultivated in Sudan I. Pimpinella anisum L (Anise) and Anethum graveolens L. (Dill). J. Pharmacogn. Phytochem., 6(1), 109-112.

Hyung W.K., Soon-Il K., Yoon J.S., Jung J.W., Hong K.B., and Ahn Y.J., 2012. Toxicity and repellency of origanum essential oil and its components against Tribolium castaneum (Coleoptera: Tenebrionidae) adults. J. Asia-Pac. Entomol. 13 (4), 369-373. 
Iordache A., Culea M., Gherman C., and Cozar O., 2009. Characterization of some plant extracts by GC-MS. Nuclear Instruments and Methods in Physics Research Section B: Beam Interactions with Materials and Atoms, 267(2), 338-342.

Isman M.B., and Machial C.M., 2006. Pesticides based on plant essential oils: from traditional practice to commercialization. Advances in phytomedicine, 3, 29-44.

Kanda D., Kaur S., and Koul O., 2017. A comparative study of monoterpenoids and phenylpropanoids from essential oils against stored grain insects: acute toxins or feeding deterrents. J. Pestic. Sci., 90(2), 531-545.

Ladan Moghadam A.R., 2016. Chemical Composition and Antioxidant Activity Cuminum cyminum L. Essential Oils. Int. J. Food Prop., 19(2), 438-442.

Manickavasagan A., Jayas D.S., and White N.D.G., 2008. Thermal imaging to detect infestation by Cryptolestes ferrugineus inside wheat kernels. J. Stored Prod. Res., 44(2), 186-192.

Moghaddam M., Miran S.N.K., Pirbalouti A.G., Mehdizadeh L., and Ghaderi Y., 2015. Variation in essential oil composition and antioxidant activity of cumin (Cuminum cyminum L.) fruits during stages of maturity. Ind. Crops Prod., 70, 163-169.

Nakakita H., 1998. Stored rice and stored product insects. Rice Inspection Technology Manual. ACE Corporation, Tokyo, Japan, 49-65.

Nenaah G.E., and Ibrahim S.I., 2011. Chemical composition and the insecticidal activity of certain plants applied as powders and essential oils against two stored-products coleopteran beetles. J. Pestic. Sci., 84(3), 393.

Nikpay A., 2007. Insecticidal efficacy of three vegetable oils as post-harvest grain protectants of stored wheat against Rhyzopertha dominica (F.)(Coleoptera: Bostrychidae). Insect science, 14(2), 145-150.

Nukenine E.N., Adler C., and Reichmuth C., 2007. Efficacy evaluation of plant powders from Cameroon as post-harvest grain protectants against the infestation of Sitophilus zeamais Motschulsky (Coleoptera: Curculionidae). J. Plant Dis. Prot., 3036.
Ozcan M.M., and Chalchat J.C., 2006. Chemical composition and antifungal effect of anise (Pimpinella anisum L.) fruit oil at ripening stage. Ann. Microbiol., 56(4), 353-358.

Papachristos D.P., and Stamopoulos D.C., 2002.Repellent, toxic and reproduction inhibitory effects of essential oil vapours on Acanthoscelides obtectus (Say) (Coleoptera: Bruchidae). J. Stored Prod. Res., 38(2), 117-128.

Roby M.H.H., Sarhan M.A., Selim K.A.H., and Khalel K.I., 2013. Antioxidant and antimicrobial activities of essential oil and extracts of fennel (Foeniculum vulgare L.) and chamomile (Matricaria chamomilla L.). Ind. Crops Prod., 44, 437-445.

Shojaaddini M., Moharramipour S., and Sahaf B., 2008. Fumigant toxicity of essential oil from Carum copticum against Indian meal moth, Plodia interpunctella. J. Plant Prot. Res., 48(4), 411-419.

Sousa A.H., Faroni L.D.A., Pimentel M.A.G., and Guedes R.N.C., 2009. Developmental and population growth rates of phosphine-resistant and susceptible populations of stored-product insect pests. J. Stored Prod. Res., 45(4), 241-246.

Weaver D.K., and Subramanyam B., 2000. Botanicals. In Alternatives to Pesticides in Stored-product IPM (pp. 303-320). Springer US.

Yoon C., Kang S.H., Jang S.A., Kim Y.J., and Kim G.H., 2007. Repellent efficacy of caraway and grapefruit oils for Sitophilus oryzae (Coleoptera: Curculionidae). J. Asia-Pac. Entomol., 10(3), 263267.

Ziaee M., Moharramipour S., and Mohsenifar A., 2014. MA-chitosan nanogel loaded with Cuminum cyminum essential oil for efficient management of two stored product beetle pests. J. Pestic. Sci., 87(4), 691-699.

\section{Sitophilus oryzae التحليل الكيماوى والنشاط الحيوي لثلاثة من الزيوت الاساسية ضد حشرتى سوسة الارز

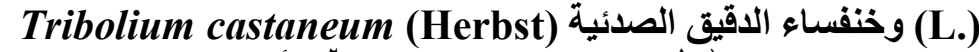

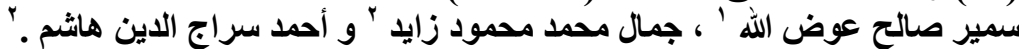

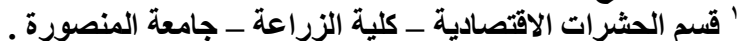

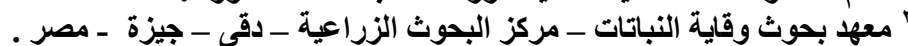

فيى هذه الدراسة تم تقييم ثلاثة من الزيوت النباتية هم البابونج الالمانى ( زهور) ونبات اليانسون (بذور) ونبات الكمون (بذور)

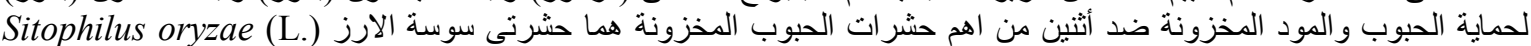

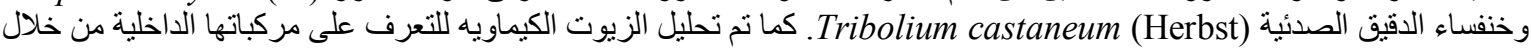

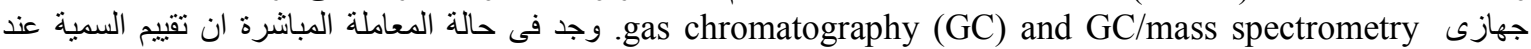

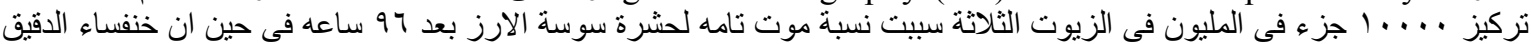

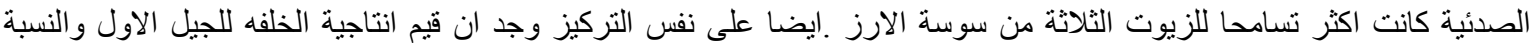

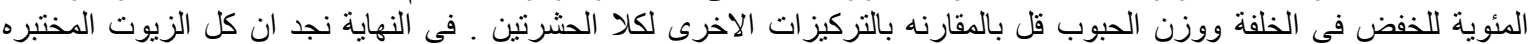

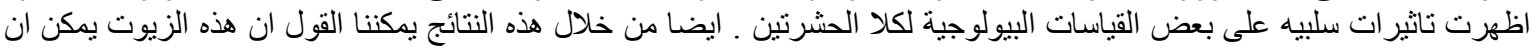
تستخدم كبديل للمبيدات الحشريه في مكافحة أفات المخازن. 